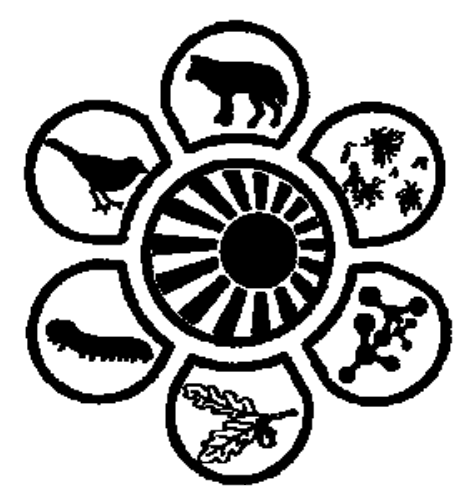

Вісник Дніпропетровського університету. Біологія, екологія.

Vìsnik Dnìpropetrovs'kogo unìversitetu. Seriâ Bìologiâ, ekologiâ

Visnyk of Dnipropetrovsk University. Biology, ecology.

Vìsn. Dnìpropetr. Unìv. Ser. Bìol. Ekol. 2015. 23(2), 161-171.

doi: $10.15421 / 011523$

ISSN 2310-0842 print

ISSN 2312-301X online

www.ecology.dp.ua

УДК 596/599:57.047

\title{
Динамічна стійкість угруповання земноводних короткозаплавних лісових екосистем
}

\author{
О.В. Жуков, Н.Л. Губанова
}

Дніпропетровський наџіональний університет імені Олеся Гончара, Дніпропетровськ, Украӥна

Надано оцінку стійкості популяцій земноводних на основі даних динаміки чисельності. Зроблено спробу оцінити напрям динамічних змін популяцій земноводних. Визначено швидкість відхилення системи від стаціонарного стану внаслідок впливу можливих чинників навколишнього середовища за допомогою такого поняття як реактивність, ступінь реактивності та еластичності системи із застосуванням їх індексів. Установлено, що стаціонарний стан угруповань земноводних заплави р. Самара стійкий. Характерною ознакою є еластичність системи. Підтверджено еластичність системи особин Bufo bufo (Linnaeus, 1758). Визначено Pelobates fuscus (Laurenti, 1768) як фактор стійкості екосистеми у кількісному відношенні. Встановлено залежність динамічних показників популяцій від їх чисельності за допомогою рівняння регресії. Динаміка угруповання залежить від дії можливих предикторів, у відповідь на яких популяція B. bufo не змінюється. Стаціонарний стан угруповання нестабільний відносно динамічної матриці, яка описує поведінку угруповання в околиці першого стаціонарного стану. Другий стаціонарний стан стабільний, але система повертається у нього протягом хвилеподібної динаміки. На основі проведених досліджень встановлено, що чисельність угруповань земноводних залишається стійкою, системи поводяться по-різному, динаміка їх повернення до стаціонарного стану еластична або реактивна.

Ключові слова: динаміка популяцій; стаціонарний стан; Bufo bufo; Bombina bombina; Rana arvalis; Pelobates fuscus

\section{Dynamic stability of communities of amphibians in short-term-flooded forest ecosystems}

\author{
O.V. Zhukov, N.L. Gubanova \\ Oles Honchar Dnipropetrovsk National University, Dnipropetrovsk, Ukraine
}

\begin{abstract}
The estimation of stability of amphibian populations on the basis of data of population dynamics is given. The paper shows an attempt to estimate the direction of dynamic changes of amphibian populations, and defines the rate of the system deviation from the stationary state due to possible influence of the environmental factors by using concepts such as reactivity, degree of reactivity and flexibility of the system when using their indexes. It is found that populations of amphibians are quite stable with regard to quantifying these species. Characteristic feature is the elasticity of the system. It is confirmed by the elasticity of the system species Bufo bufo (Linnaeus, 1758). Type Pelobates fuscus (Laurenti, 1768) is defined as a factor of stability of the system in quantitative terms. Dependence of dynamics of the population on its size is established using the regression equation. Dynamics of groups depends on the action of possible predictors in response to which the population of $B$. bufo is not changed. The ecosystem is characterized as a place of interaction between biotic factors and factors of abiotic origin, which are due to the external action. Internal factor of the ecosystem stability is the influence of some amphibian populations on the other ones. The system features sustainable and relatively stable number of $B$. bufo, which does not affect the level of its stability. Stationary state of the grouping is unstable due to dynamic matrix, which describes the behavior of the group in the vicinity of the first stationary state. The second steady state is stable one, and the system returns to the stationary state with the help of wave-like dynamics. On the basis of our study it is established that the number of groups of amphibians remains stable, the systems behave differently, and dynamics of their return to the stationary state is elastic or reactive one. Ecosystems within lime-ash oak forests in the Central floodplain of the Samara river represent relatively stable populations of amphibians. The constant number of individuals in the population confirms stability of the ecosystem. The regression equation indicates the dependence of the dynamic performance of the system on the number of amphibians.
\end{abstract}

Keywords: dynamics of populations; stationary state; Bufo bufo; Bombina bombina; Rana arvalis; Pelobates fuscus

Дніпропетровський національний університет імені Олеся Гончара, пр. Гагаріна, 72, Дніпропетровськ, 49010, Україна Oles Honchar Dnipropetrovsk National University, Gagarin Ave., 72, Dnipropetrovsk, 49010, Ukraine Tel.: +38-056-760-84-38.E-mail:nlg2@list.ru 


\section{Ветуп}

Один із ключових показників успішного існування популяцій - їх самовідновлення. Самовідновлення популяцій, підтримання стійкості та збереження біорізноманіття важливі характеристики, які вказують на здатність до тривалого існування системи (Carik, 2010). Теоретичні моделі вказують на те, що багатовидові угруповання 3 сильними взаємодіями між видами не можуть бути стійкими (Мау, 1974). Для визначення сили взаємодії між видами розроблено декілька підходів. Найбільш ранні техніки застосовували оцінку перекривання ніш (MacArthur and Levins, 1967; Pianka, 1973), порівняння морфологічних особливостей (Ricklefs and Travis, 1980) та статичну регресію чисельності видів між собою в різних сайтах (Schoener, 1974; Hallett and Pimm, 1979). Ці підходи зазнали критики як такі, що не надають припущень, які підтверджуються експериментально (Laska and Wootton, 1998). Значну результативність показав динамічний регресійний аналіз, при якому досліджуються часові ряди даних чисельності видів, при цьому залежною змінною виступає швидкість зміни чисельності видів (Wootton, 1994; Pfister, 1995; Chase, 1996).

Для оцінки стійкості екологічного угруповання Р. Мей (Мау, 1974) запропонував підхід, який грунтується на застосуванні коефіцієнтів кореляції між чисельністю видів в угрупованні. Середня сила статистичного зв'язку між компонентами системи R (середній коефіцієнт кореляції) може розглядатися як показник іiі жорсткості та організованості. Для розрахунку жорсткості можна застосовувати коефіцієнти кореляції як Пірсона, так і Спірмена (Mihaylovskiy, 1988; Shadrin, 2012). За Р. Мей (Мау, 1974), стійкість екосистеми може бути встановлена за наступним критерієм:

$$
\mathrm{R}<(\mathrm{SC})^{-1 / 2}
$$

де $\mathrm{R}$ - жорсткість системи, $\mathrm{S}$ - кількість елементів у системі, C - зв'язність (кількість ребер графу, віднесена до максимально можливої їх кількості $\mathrm{S} *(\mathrm{~S}-1) / 2)$.

Показники, що характеризують стан популяцій та угруповань, є інформаційно цінними 3 точки зору оцінки стану біоценозів у цілому та їх динаміки в процесі існування (Reshetilo, 2013). За впливу чинників різного походження змінюється склад біосистем на всіх рівнях організації. На популяційно-видовому рівні відбуваються зміни структури популяції, пов'язані з чисельністю особин та ареалом їх існування. Одним із найважливіших чинників для самовідновлення популяцій тварин $\epsilon$ їх здатність до переміщення у просторі. Найбільш характерні переміщення тварин у просторі, зокрема хребетних, - це сезонні міграції (Ishhenko, 2007). Саме під час міграцій особини стикаються 3 багатьма екологічними обставинами - як природними, так і антропогенними, частина 3 яких може мати вирішальне значення для самовідновлення популяцій (Orlowski, 2004; Kusak, 2009).

Екологічні системи зазнають впливу факторів зовнішнього середовища. Їх реакція на пертурбації характеризується якісно поняттям «стабільність», що відбиває відповідь системи на пертурбації (повертається система у вихідний стан після пертурбації чи ні). Крім того, існує кількісна характеристика - еластичність системи, що вимірює, як швидко відбувається повернення у вихідний стан після пертурбації (Holling, 1973; Beddington et al., 1976; Harrison, 1979; Pimm, 1979, 1984; DeAngelis, 1980). Теоретичні та експериментальні роботи в екології були спрямовані на вивчення впливу на еластичність екосистемних характеристик, таких як потік енергії (O'Neill, 1976; DeAngelis, 1980), кількість і кругообіг поживних речовин (Harwell et al., 1977; DeAngelis, 1980; DeAngelis et al., 1989; Cottingham, Carpenter, 1994; Loreau, 1994), стохастичність умов навколишнього середовища (Ives, 1995), довжина трофічних ланцюгів (Pimm and Lawton, 1977; Vincent and Anderson, 1979; DeAngelis et al., 1989; Carpenter et al., 1992; Cottingham and Carpenter, 1994), вплив фітофагів (Lee and Inman, 1975) і тварин із широкими трофічними режимами (Pimm and Lawton, 1978; Pimm, 1979).

Запропоновано велику кількість індексів для вимірювання еластичності екосистем (Jordan et al., 1972; Pimm and Lawton, 1977; DeAngelis, 1980). Найчастіше зустрічається та досить просто може бути обчислений індекс, що грунтується на власних числах матриці, яка характеризує динаміку системи поблизу рівноваги (Neubert and Caswell, 1997).

Розглянемо лінійну систему:

$$
\frac{d x}{d t}=A^{*} x, x(0)=x_{0},
$$

яка може представляти лінійну систему або лінеаризацію нелінійної системи поблизу точки рівноваги. Рівняння (1) має єдине рішення:

$$
x(t)=e t x_{0} .
$$

Якщо власне число матриці А $є$ негативним, то $\mathrm{e}^{\mathrm{At}} \rightarrow$ 0 при $\mathrm{t} \rightarrow \infty$, а рівноважне рішення $\mathrm{X}^{*}=0 \epsilon$ асимптотично стабільним.

Через те, що швидкість асимптотичного зменшення $\mathrm{x}$ пропорційна степеню 1/е в часовому інтервалі-1/Re $(\lambda 1(A))$, Pimm i Lawton (1977) використали зазначений інтервал як міру часу повернення до стаціонарного рівноважного стану. Таким чином, еластичність (Resilience) визначається як:

$$
\text { Resilience } \equiv-1 / \operatorname{Re}(\lambda 1(A)) \text {, }
$$

$\epsilon$ асимптотичною апроксимацією швидкості згасання пертурбації лінійної системи (1). У разі більшої еластичності пертурбації загасають швидше. Еквівалентна версія для дискретної системи (3) широко використовується в екологічних дослідженнях (Beddington et al., 1976; Pimm and Lawton, 1977, 1978; Harwell and Ragsdale, 1979; Pimm, 1979, 1982, 1984; Vincent and Anderson, 1979; DeAngelis, 1980; Harwell et al., 1981; Armstrong, 1982; DeAngelis at al., 1989a, 1989b; Carpenter et al., 1992; Nakajima, 1992; Cottingham and Carpenter, 1994; Loreau, 1994).

Еластичність, обчислена за допомогою найбільшого за модулем власного числа матриці $A(4), \epsilon$ асимптотичною властивістю, що відбиває швидкість загасання пертурбації із часом. Короткочасна поведінка системи відразу після пертурбації при цьому ігнорується. Виникає питання, чи відбиває адекватно асимптотична поведінка відповідь на вплив? Через коротку тривалість більшості екологічних експериментів швидкоплинні ефекти переважають під час спостережень за реакцією екосистем на пертурбації. Крім того, швидкоплинні реакції системи можуть бути так само важливі, як і три- 
вала асимптотична поведінка. Навіть стабільна еластична система у перший період після пертурбації може поводитись досить драматично та контрінтуїтивно. Навіть якщо пертурбація згодом загасає, iї розмір може швидко збільшуватися у початковий період реакції системи. Швидкоплинні зміни не є результатом нелінійності системи, хоча нелінійність може посилювати ефект (Neubert and Caswell, 1997).

Показник швидкості зміни чисельності популяції вказує на тренд динаміки популяції у перспективі та може бути обчислений за ретроспективними даними.

У нашій попередній праці (Zhukov and Gubanova, 2015) показано, що серед досліджених факторів найбільшу роль у формуванні різноманіття угруповання амфібій у заплавних біогеоценозах р. Самара відіграє фактор сезонності. Загальний чинник, який впливає на чисельність тварин, - стабільність структури метаугруповання амфібій, що відображено за допомогою індексів різноманіття. Фактор року майже не впливає на стан популяцій амфібій, що проявляється у стабільному розподілі популяцій за парцелами біогеоценозу та інваріантному стосовно років співвідношенню чисельностей популяцій, які складають угруповання. Стабільний рівень видового багатства угруповання амфібій у досліджуваному біогеоценозі робить головною причиною варіабельності різноманіття зміну чисельності видів. Варіабельність різноманіття між сайтами зумовлена динамікою чисельності саме численних видів.

У цій статті ми маємо на меті висвітлити аспект кореляційних зв'язків між чисельністю видів угруповання амфібій, що є основою оцінки стійкості угруповання за Р. Мейєм. У результаті моделювання динаміки чисельності популяцій в угрупованні ми зможемо одержати динамічні матриці угруповання, які формально дозволяють встановити якісно стан угруповання як стійкий або нестійкий за Ляпуновим i дослідити кількісно характеристики його стійкості - еластичність і реактивність.

\section{Матеріал і методи досліджень}

Матеріал цієї роботи зібрано по сезонах у 2002 2004 роках у межах липово-ясеневої діброви в центральній заплаві р. Самара, пробна площа 209 екологічного профілю ННЦ ДНУ імені Олеся Гончара «Присамарський біосферний стаціонар імені О.Л. Бельгарда». Досліджене угруповання амфібій представлене сукупністю особин певних видів, які можна ідентифікувати як ценнопопуляції, або точніше - поліценотичні популяції тварин, які вільно перемішуються, але пов'язані з даним ценозом (Bikov, 1983). У подальшому у статті розглядається чисельність саме ценотичних компонент у рамках липово-ясененовї діброви таких поліценотичних популяцій.

Облік амфібій проведено на пробних ділянках за допомогою ловчих траншей кільцевої форми. Діаметр траншеї складав 5,2 м, глибина - 0,4 м, ширина - 0,2 м. У кожній частини кола, яка відповідає півночі, півдню, заходу та сходу були розташовані ловчі циліндри. Циліндри мали діаметр 0,2 м та висоту 0,4 м і були вкопані на дні кільцевої траншеї до верхнього рівня. У межах пробної площі 209 закладено три ловчі траншеї. Вибирання тварин відбувалося вранці кожного дня протягом періоду спостережень. У 2002 році обліки проведено влітку - 31 по 10 липня, восени - 316 по 25 вересня; у 2003 році - навесні - 312 по 21 травня, влітку з 1 по 10 липня, восени - з 16 по 25 вересня; у 2004 році навесні - 12 по 23 травня, влітку - 31 по 10 липня, восени - 316 по 25 вересня (деталі - Zhukov and Gubanova, 2015). Загальна кількість дат обліку становить 237 , було спіймано Bufo bufo (Linnaeus, 1758) - 562 екз., Bombina bombina (Linnaeus, 1758) - 1157 екз., Rana arvalis Nilsson, 1842 - 1465 екз., Pelobates fuscus (Laurenti, 1768) - 1629 екз.

Для приведення до нормального закону розподілу експериментальні дані щодо чисельності амфібій трансформовано за допомогою перетворення Бокса - Кокса. Параметр $\lambda$ трансформації обраховано для кожної популяції окремо за допомогою пакета AID (Asara et al., 2015).

Корекція для множинного порівняння була проведена за допомогою пакета lsr методом Хольма (Navarro, 2015). За допомогою цього пакета обраховано кореляційні матриці з коефіцієнтами кореляції Пірсона та Спірмена.

Для розрахунку жорсткості угруповання $\mathrm{R}$ знайдено середнє значення статистично вірогідних парних коефіцієнтів кореляції Спірмена. Кількість елементів у системі відповідає видовому багатству та у нашому випадку дорівнює $\mathrm{S}=4$. Зв'язність С обчислюється як відношення кількості статистично вірогідних кореляційних зв'язків до максимально можливого $S^{*}(S-1) / 2$. За Г. Міхайловським (1988), критерій стійкості Мея переписано у вигляді:

$$
\mathrm{R}(\mathrm{SC})^{1 / 2}<1 .
$$

Динамічну поведінку популяції можна охарактеризувати за допомогою швидкості зміни чисельності, яка може бути встановлена через чисельне диференціювання ряду чисельностей популяції:

$$
\frac{\Delta x_{i, j}}{\Delta t}=x_{i+1, j}-x_{i, j},
$$

де $x_{i}$ та $x_{i+1}$ чисельність $j$-ї популяції в моменти часу $i$ та $i+1$ відповідно. Часовий лаг $i$ склав 1 добу, що відповідає інтервалам часу між вибиранням проб із ловчих циліндрів.

Для дослідження динаміки угруповання на предмет стійкості за Ляпуновим необхідні такі етапи (Sumarokov and Zhukov, 2007). По-перше, динаміка угруповання повинна бути описана в термінах диференціальних рівнянь. По-друге, на підставі системи диференціальних рівнянь будується динамічна матриця угруповання (одна або декілька, залежно від кількості стаціонарних станів). Динамічна матриця угруповання складається 3 коефіцієнтів часткових похідних, тому цей екологічний термін у термінах класичної математики зветься Якобіаном. Потім на основі отриманих матриць обчислюються критерії стійкості угруповання, на підставі яких робиться висновок про характер його стійкості.

За основу опису динаміки угруповання взято каскадні рівняння Лотки - Вольтерра, що загалом мають вигляд (Chen and Cohen, 2001):

$$
\frac{d x_{i}}{d t}=x_{i} *\left(r_{i}+f\left(\frac{x_{i}}{K}, \ldots x_{j}\right)\right) \text {, }
$$

де $d x_{i} / d t$ - швидкість зміни популяції, $x_{i}$ - щільність популяції, $r_{i}$ - максимальна швидкість росту, $K$ - гранична щільність популяції, вище якої швидкість росту стає нега- 
тивниою, $f$ - функціональна залежність кількісних змін показників популяції від щільності популяцій, що входять до складу угруповання.

Характер математичної форми $f$ може відбивати екологічну специфіку взаємодії, звідки й виникають різновиди рівняння Лотки - Вольтерра. У формі $f$ можна врахувати конкуренцію, хижацтво, мутуалізм тощо (Chen and Cohen, 2001).

Для опису динаміки реального угруповання крім якісної відповідності математичної форми специфіці взаємодії як важливий критерій включається вимога оптимальності моделі. Критерій оптимальності має на увазі деяке співвідношення між точністю опису реальних даних, кількістю змінних у моделі та складністю їх взаємозв'язку. Інакше, зі збільшенням кількості предикторів і складності взаємозв'язку можна одержати гарний формальний опис явища, але таке рішення буде складно інтерпретувати якісно.

Для опису кількісної динаміки структури угруповання амфібій застосовано каскадні моделі Лотки - ВольTeppa (Chen and Cohen, 2001):

$$
\begin{aligned}
& \frac{d x_{i}}{d t}=x_{i} *\left(r_{i}+a 1 \cdot x 1+\ldots+a 4 \cdot x 4+a 5 \cdot x 1^{2}+\right. \\
& \left.+\ldots a 8 \cdot x 4^{2}+a 9 \cdot x 1 \cdot x 2+\ldots a 14 \cdot x 3 \cdot x 4\right),
\end{aligned}
$$

де $a 1 \ldots a 14$ - коефіцієнти, які вказують на ступінь впливу чисельності видів (лінійні компоненти) та взаємодії між видами (компоненти другого ступеня). Функціональна залежність кількісних змін показників популяції від щільності популяцій, що входять до складу угруповання, має вигляд полінома другого ступеня. Коефіцієнти взаємодії між видами можуть бути встановлені за допомогою нелінійної регресійної моделі (метод найменших квадратів, метод оцінювання Левенберга - Марквардта). Попередній аналіз для простішої лінійної моделі показав, що вона неадекватно описує залежність, оскільки регресійні залишки характеризувались значною асиметрією.

Система рівнянь другого ступеня має два рішення, які відповідають стаціонарним станам динамічної системи. В околицях цих станів система може бути лінеаризована i таким чином представлена у вигляді Якобіана (умовно позначається як $A$ ), власне число якого вказує на стійкість або нестійкість стаціонарного стану (Sumarokov and Zhukov, 2007).

Швидкість відхилення системи від стаціонарного стану внаслідок впливу характеризується таким поняттям як реактивність. Вона може бути обчислена в такий спосіб (Neubert and Caswell, 1997):

Reactivity $=\lambda 1\left(\left(\mathrm{~A}+\mathrm{A}^{\mathrm{T}}\right) / 2\right)$,

де $A$ - Якобіан. Якщо $\lambda 1(A)<0$, а $\lambda 1\left(\left(\mathrm{~A}+\mathrm{A}^{\mathrm{T}}\right) / 2\right)>0$, то система $є$ стійкою, але реактивною. Тому пертурбації, не настільки важливо, якими малими за розмірами вони $\epsilon$, перш ніж затихнути, будуть збільшуватися.

Реактивність $€$ мірою поведінки системи при $\mathrm{t} \rightarrow 0 \mathrm{i}$ доповнює еластичність, що $є$ мірою поводження системи при $\mathrm{t} \rightarrow \infty$. Якщо система реактивна, то після виведення з рівноважного стану величина відхилення буде збільшуватися. Це відхилення характеризується максимальною величиною та часом його досягнення. Еластичність і реактивність є мірами, які визначають амплітуду відхилення системи в неврівноваженому стані. Еластичність чисельно збігається з нахилом траєкторії системи при прагненні часу до нескінченності. Реактивність чисельно збігається
3 нахилом траєкторії поведінки системи при прагненні часу до нуля.

Латинські назви видів наведено за базою даних Fauna Europaea (de Jong et al., 2014).

\section{Результати}

У результаті застосування наведеної методики обліку встановлено, що у період дослідження угруповання амфібій липово-ясеневої діброви у центральній заплаві p. Самара представлене такими видами: P. fuscus, R. arvalis, B. bufo, B. bombina. Інформацію про батрахофауну заплави р. Самара наведено у багатьох дослідженнях співробітників Комплексної експедиції ДНУ (Bulakhov et al., 2007; Pakhomov et al., 2011).

Кореляційні матриці за коефіцієнтами як Спірмена, так і Пірсона, дають подібні результати (табл. 1).

Кореляційна матриця чисельності амфібій

Таблиия 1

\begin{tabular}{|l|c|c|c|c|}
\hline \multicolumn{1}{|c|}{ Вид } & B. bufo & B. bombina & R. arvalis & P. fuscus \\
\hline B. bufo & 1,00 & 0,27 & - & - \\
\hline B. bombina & 0,23 & 1,00 & 0,76 & 0,59 \\
\hline R. arvalis & - & 0,75 & 1,00 & 0,79 \\
\hline P. fuscus & - & 0,59 & 0,79 & 1,00 \\
\hline
\end{tabular}

Примітки: верхня напівматриця - коефіцієнти кореляції Пірсона для трансформованих даних, нижня напівматриця коефіцієнти кореляції Спірмена для даних без трансформації; наведено тільки вірогідні коефіцієнти кореляції для $\mathrm{P}<0,05$.

При проведенні кореляційного аналізу виявлено статистично вірогідну взаємозалежність між чисельностями популяцій часникової жаби та гостромордої ропухи. Слід відзначити позитивну кореляцію чисельностей популяцій кумки червоночеревої та ропухи гостромордої та між представниками кумки червоночеревої та часникової жаби. Відносно невелика залежність характерна для жаби звичайної та кумки червоночеревої. Не відмічено статистично вірогідної кореляції між чисельністю жаби звичайної та ропухи гостромордої та часникової жаби.

На рисунку 1 наведено попарні діаграми розсіювання чисельності амфібій, які дозволяють встановити характер зв'язків між дослідженими популяціями. Дані рисунка 1 певною мірою доповнюють результати кореляційного аналізу (табл. 1), але слід зазначити, що коефіцієнти кореляції Пірсона, обчислені при кореляційному аналізі, здатні відобразити тільки лінійну компоненту зв'язку. Як ми бачимо на рисунку, лінійна компонента є суттєвою для парних кореляцій B. bombina, R. arvalis та P. fuscus. Кореляції чисельності популяцій $B$. bufo з іншими амфібіями мають суттєву нелінійну компоненту, що у термінах лінійної моделі відображається як зниження вірогідності відповідних кореляційних коефіцієнтів. Також очевидно, що коефіцієнт рангової кореляції Спірмена теж не завжди чутливий до деяких форм екологічних взаємозв'язків. Таким чином, статистично не вірогідні лінійні коефіцієнти кореляції ще не є свідченням відсутності зв'язку як такого. У нашому випадку зв'язок має складніший характер, ніж такий, що може бути відображений у рамках лінійного підходу. На основі коефіцієнтів рангової кореляції Спірмена обчислено показники стійкості угруповання амфібій за Р. Меєм (табл. 2). 

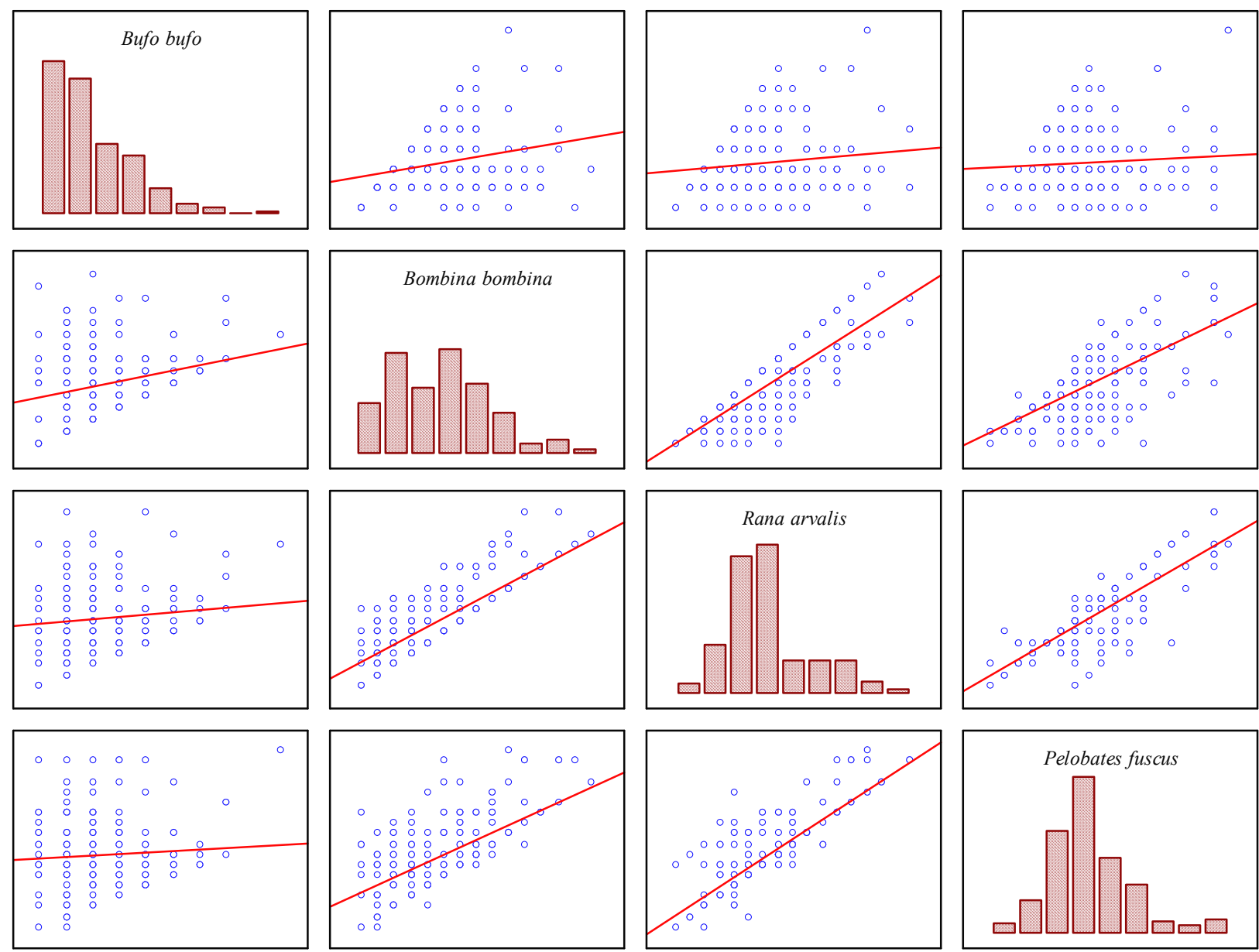

Рис. 1. Гістограми розподілу чисельності амфібій та діаграми розсіювання:

по осі абсцис та ординат - чисельність видів земноводних, позначених на діагоналі, одиниці (екз./10 пастко-діб) пропущені для спрощення подання матеріалу)

Таблиия 2

Оцінка стійкості угруповання амфібій за Р. Месм

\begin{tabular}{|l|c|c|c|c|}
\hline Аспект угруповання & $R$ & $C$ & $R(S C)^{1 / 2}$ & $\begin{array}{c}\text { Оцінка } \\
\text { стійкості } \\
\text { угруповання }\end{array}$ \\
\hline \multicolumn{5}{|c|}{ По роках } \\
\hline 2002 & 0,48 & 0,61 & 0,79 & стійке \\
\hline 2003 & 0,79 & 0,71 & 1,11 & не стійке \\
\hline 2004 & 0,55 & 0,54 & 1,02 & не стійке \\
\hline По сезонах \\
\hline Весна & 0,31 & 0,71 & 0,44 & стійке \\
\hline Літо & 0,61 & 0,61 & 1,00 & нейтральне \\
\hline Осінь & 0,51 & 0,55 & 0,93 & стійке \\
\hline \multicolumn{5}{|c|}{ По парцелах } \\
\hline Мокрицева 0,55 & 0,61 & 0,90 & стійке \\
\hline Мертвопокривна & 0,61 & 0,61 & 1,00 & нейтральне \\
\hline Яглицева & 0,6 & 0,61 & 0,98 & стійке \\
\hline \multicolumn{6}{|c|}{0,59} & 0,61 & 0,97 & стійке \\
\hline Усього вась період по усіх парцелах
\end{tabular}

Угруповання амфібій як цілісна система у межах дослідженого просторового та часового діапазонів характеризується стійкістю. У часовому аспекті стан стійкості встановлений тільки для 2002 р., тоді як динаміка угруповання у 2003 та 2004 рр. стійкою не була. Хоча спостережуване відхилення від стійкого стану більшою мірою можна визнати як прояв нейтральної стійкості. У сезон- ному аспекті стійкістю характеризується динаміка навесні та восени, а влітку динаміка нейтральна. У біогеоценотичному аспекті стійкою є динаміка в мокрицевій та яглицевій парцелах, тоді як динаміка угруповання в мертвопокривній парцелі нейтральна. Таким чином, обрахування кореляційної матриці чисельності угруповання амфібій дозволило встановити емпіричні метрики стійкості за Р. Меєм. Найважливішим результатом $є$ тотальна стійкість угруповання, тоді як в окремих аспектах поряд із переважанням стійких станів можуть спостерігатися нейтральні або нестійкі стани угруповання.

Слід зазначити, що парні кореляційні залежності чисельностей популяцій відображають статичний аспект організації угруповання, який проявляє себе вже як певний результат взаємодій між популяціями та результат впливу зовнішніх факторів. Динамічна компонента може бути відображена за допомогою визначення швидкостей зміни чисельностей популяцій у часі.

Аналіз залежностей швидкостей змін чисельностей популяцій досліджених популяцій амфібій від чисельності $B$. bufo дозволив установити закономірні патерни динаміки чисельності земноводних (рис. 2).

Швидкість зміни чисельності B. bufo від'ємно залежить від чисельності самого виду, що свідчить про наявність механізмів негативного зворотного зв'язку, які стабілізують популяцію. Цікавіші інші залежності. Швидкість зміни чисельності $B$. bombina максимальна за 
чисельності B. bufo 3-4 екз./пастко-добу. Збільшення або зменшення чисельності $B$. bufo зумовлює зменшення швидкості росту чисельності популяції $B$. bombina. Аналогічну форму залежностей встановлено також для динаміки чисельності $R$. arvalis та $P$. fuscus від чисельності B. bufo. Парабола досить добре може описати відповідні залежності геометрично, а поліном другого степеня - аналітично. Другий степінь в аналітичних залежностях вказує на взаємозв'язок, який виникає у разі здійснення впливу. Це можна інтерпретувати як взаємозв'язок між особинами у популяції $B$. bufo, який виникає за впливу на інші популяції угруповання амфібій.

Гіперболічний характер має залежність швидкості динаміки B. bombina від щільності популяції цього виду (рис. 3). Подібний характер впливу чисельності B. bom-
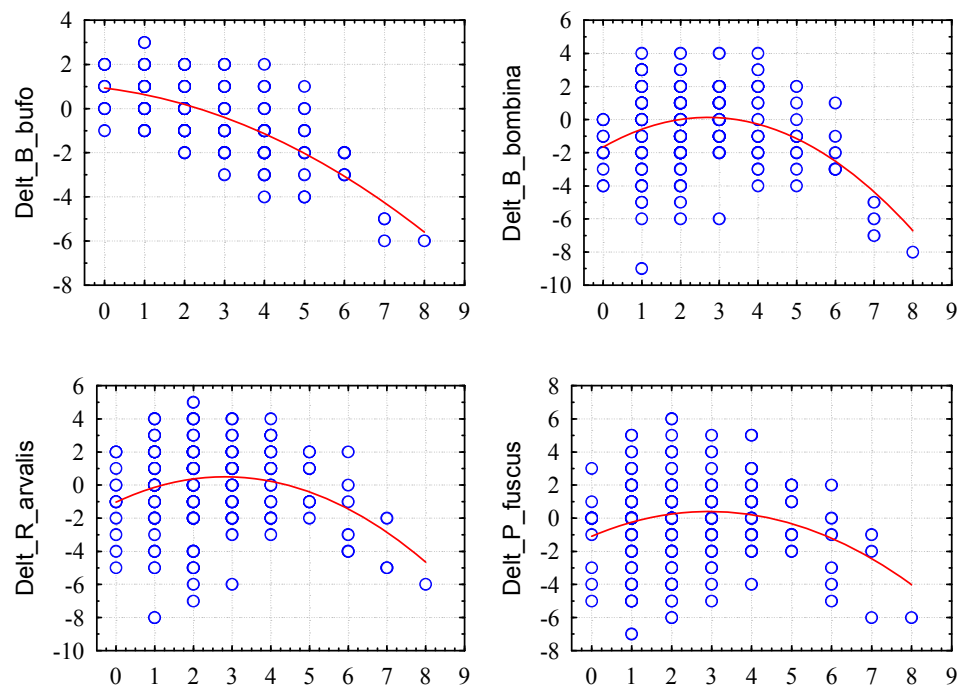

Рис. 2. Залежність швидкості зміни чисельності популяцій амфібій (вісь ординат, Delt, екз./10 пастко-діб ${ }^{-2}$ ) від чисельності В. bufo (вісь абсцис, екз./10 пастко-діб)
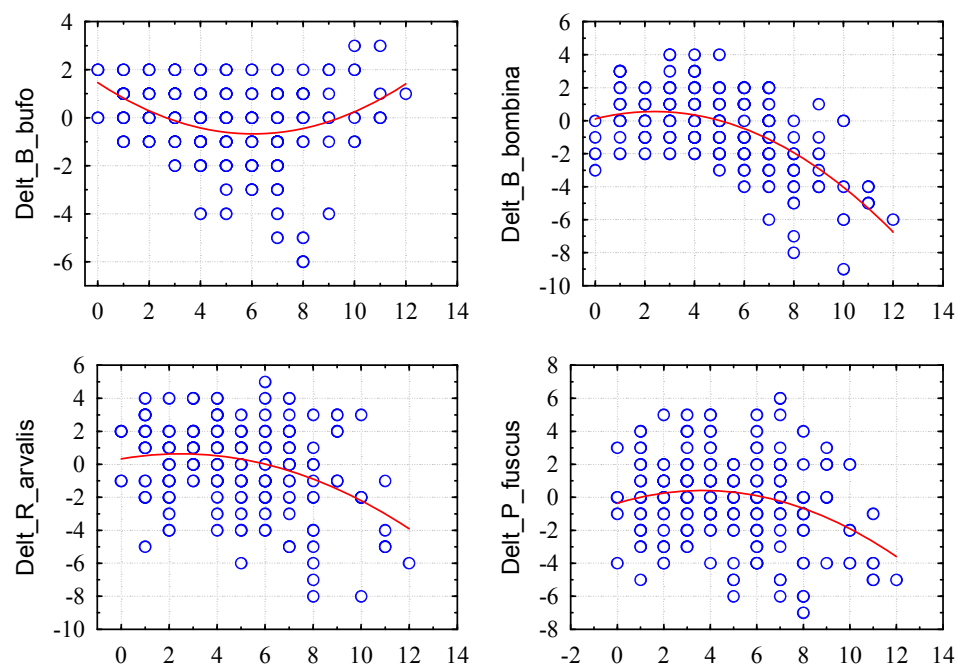

Рис. 3. Залежність швидкості зміни чисельності популяцій амфібій (вісь ординат, Delt) від чисельності В. bombina (вісь абсцис)

Важливо зазначити, що вплив чисельності популяції $R$. arvalis на динаміку популяцій в угрупованні характеризується високим рівнем подібності з тими закономірностями, що були встановлені для впливу популяції B. bombina (рис. 4). В обох випадках гіперболічні метафори досить добре відображають взаємовідносини в угрупованні. Вплив популяцій $P$. fuscus на динаміку чисельностей амфібій при загальній подібності до попередніх двох видів має більш лінійний характер. Регресійний аналіз дозволяє перейти від попарних порівнянь показників динаміки чисельності певного виду 3 чисельністю видів в угрупованні до складнішої 
моделі, яка враховує також взаємодії між видами (табл. 3). Компоненти полінома першого степеня вказують на вплив популяцій на динаміку досліджуваної популяції, а компоненти другого степеня - вплив
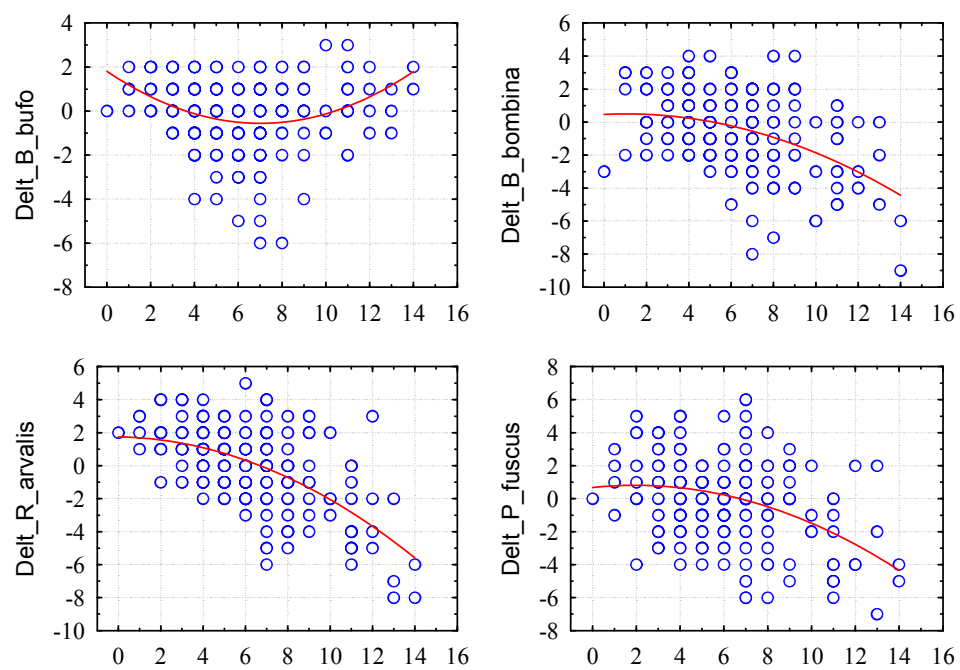

взаємодії популяцій. Регресійні моделі дозволяють пояснити 55-64\% дисперсії швидкості змін чисельності досліджених популяцій амфібій.

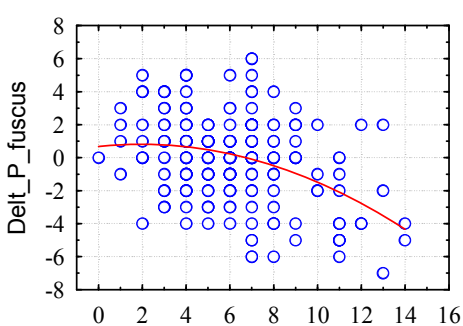

Рис. 4. Залежність швидкості зміни чисельності популяцій амфібій (вісь ординат, Delt) від чисельності $R$. arvalis (вісь абсцис)
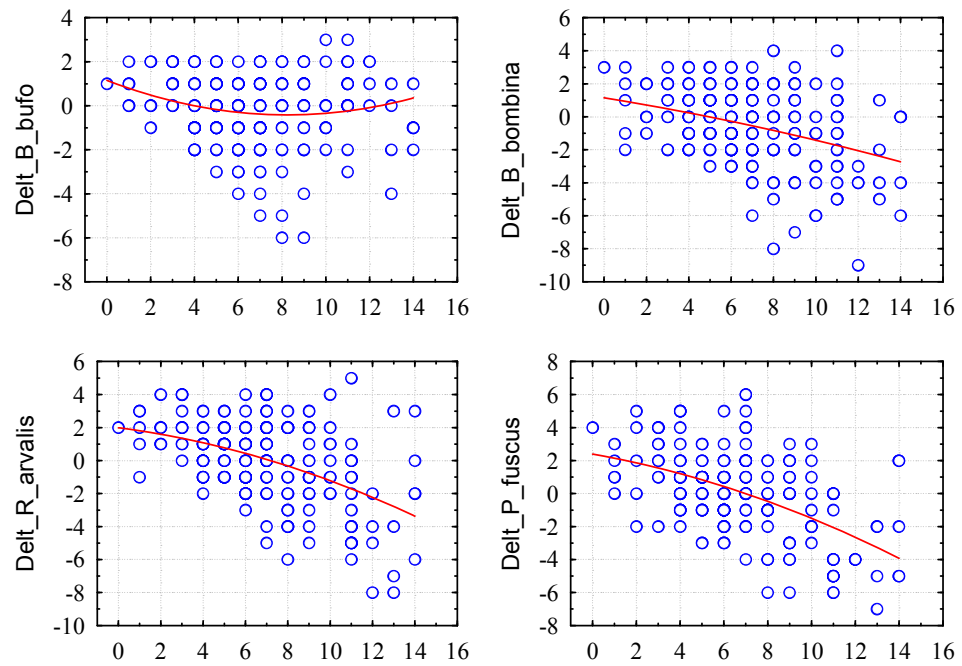

Рис. 5. Залежність швидкості зміни чисельності популяцій амфібій (вісь ординат, Delt) від чисельності P. fuscus (вісь абсцис)

Одержані регресійні рівняння складають систему рівнянь другого степеня, яка має два рішення:

Перший стаціонарний стан:

$$
\operatorname{vec}(\mathrm{x} 1, \mathrm{x} 2, \mathrm{x} 3, \mathrm{x} 4)=\left(\begin{array}{c}
4.663 \\
2.74 \\
4.033 \\
4.161
\end{array}\right) \text { । }
$$

Другий стаціонарний стан:

$$
\operatorname{vec}(x 1, x 2, x 3, x 4)=\left(\begin{array}{c}
1.704 \\
5.203 \\
7.982 \\
8.184
\end{array}\right) \text { । }
$$

Ці рішення відповідають стаціонарним станам динаміки популяцій, тобто таких, за яких швидкість зміни чисельності всіх популяцій дорівнює нулю. Для першого стаціонарного стану властиве переважання чисельності B. bufo в угрупованні амфібій, що $є$ нетиповою ситуацією під час досліджень. Другий стаціонарний стан більшою мірою відповідає типовому розподілу чисельності.

Для проведення аналізу стійкості стаціонарних станів поліноміальна функція другого порядку повинна бути лінеаризована за допомогою розвинення у ряд Тейлора в околиці стаціонарних точок. Лінеаризація дала наступні динамічні матриці, які описують поведінку угруповання в околицях відповідних стаціонарних станів:

Перший стаціонарний стан:

$$
\mathrm{S}=\left(\begin{array}{cccc}
0.057 & -0.176 & -0.09 & 0.047 \\
-0.17 & -0.095 & 0.124 & -0.067 \\
-0.188 & 0.066 & -0.03 & -0.029 \\
-0.174 & 0.09 & 0.053 & -0.141
\end{array}\right) \text { । }
$$


Другий стаціонарний стан:

$$
\mathrm{S}=\left(\begin{array}{cccc}
-0.231 & -0.004 & 0.144 & -0.117 \\
0.093 & -0.108 & 0.01 & 0.002 \\
0.049 & 0.071 & -0.099 & -0.03 \\
0.03 & 0.04 & -0 & -0.095
\end{array}\right) \text {, }
$$

Найбільше власне число динамічної матриці, яка опиисує поведінку угруповання в околиці першого стаціонарного стану, $\epsilon$ позитивним, $з$ чого випливає асимптотична нестабільність цього стаціонарного стану. Тобто при виведенні системи $з$ цього стану внаслідок зовнішньої пертурбації вона не має механізмів повернутися назад. Перебування в цьому стаціонарному стані можливе тільки як наслідок випадкового блукання траєкторії угруповання.

Динамічні рівняння чисельності амфібій

\begin{tabular}{|c|c|c|c|c|c|c|c|c|}
\hline \multirow{2}{*}{ Змінні } & \multicolumn{2}{|c|}{$\begin{array}{c}\text { B. bufo } \\
R^{2}=0,64\end{array}$} & \multicolumn{2}{|c|}{$\begin{array}{l}\text { B. bombina } \\
R^{2}=0,57\end{array}$} & \multicolumn{2}{|c|}{$\begin{array}{l}R . \text { arvalis } \\
R^{2}=0,55\end{array}$} & \multicolumn{2}{|c|}{$\begin{array}{l}P . \text { fuscus } \\
R^{2}=0,55\end{array}$} \\
\hline & \multicolumn{2}{|c|}{$\begin{array}{c}\text { середнє } \pm \text { стандартна } \\
\text { помилка, } p \text {-рівень }\end{array}$} & \multicolumn{2}{|c|}{$\begin{array}{c}\text { середнє } \pm \text { стандартна } \\
\text { помилка, } p \text {-рівень }\end{array}$} & \multicolumn{2}{|c|}{$\begin{array}{c}\text { середнє } \pm \text { стандартна } \\
\text { помилка, } p \text {-рівень }\end{array}$} & \multicolumn{2}{|c|}{$\begin{array}{c}\text { середнє } \pm \text { стандартна } \\
\text { помилка, } p \text {-рівень }\end{array}$} \\
\hline$r$ & $1,32 \pm 0,30$ & 0,00 & $0,39 \pm 0,25$ & 0,11 & $0,73 \pm 0,19$ & 0,00 & $0,90 \pm 0,22$ & 0,00 \\
\hline$x 1$ & $-0,28 \pm 0,10$ & 0,00 & $0,08 \pm 0,07$ & 0,23 & $-0,02 \pm 0,06$ & 0,72 & $-0,06 \pm 0,06$ & 0,36 \\
\hline$x 2$ & $0,05 \pm 0,09$ & 0,55 & $-0,08 \pm 0,07$ & 0,28 & $0,05 \pm 0,04$ & 0,28 & $0,09 \pm 0,05$ & 0,04 \\
\hline$x 3$ & $-0,57 \pm 0,13$ & 0,00 & $0,13 \pm 0,12$ & 0,27 & $0,02 \pm 0,08$ & 0,81 & $0,05 \pm 0,06$ & 0,46 \\
\hline$x 4$ & $0,29 \pm 0,09$ & 0,00 & $-0,15 \pm 0,09$ & 0,09 & $-0,15 \pm 0,06$ & 0,01 & $-0,25 \pm 0,05$ & 0,00 \\
\hline$x 1^{2}$ & $0,04 \pm 0,01$ & 0,00 & $-0,03 \pm 0,01$ & 0,00 & $-0,03 \pm 0,01$ & 0,00 & $-0,02 \pm 0,01$ & 0,00 \\
\hline$x 2^{2}$ & $0,03 \pm 0,02$ & 0,08 & $0,02 \pm 0,01$ & 0,15 & $-0,02 \pm 0,01$ & 0,00 & $-0,01 \pm 0,01$ & 0,32 \\
\hline$x 3^{2}$ & $0,06 \pm 0,02$ & 0,00 & $0,00 \pm 0,02$ & 0,87 & $-0,01 \pm 0,01$ & 0,28 & $0,00 \pm 0,01$ & 0,68 \\
\hline$x 4^{2}$ & $-0,02 \pm 0,01$ & 0,01 & $0,02 \pm 0,01$ & 0,01 & $0,01 \pm 0,01$ & 0,02 & $0,01 \pm 0,00$ & 0,01 \\
\hline$x 1 \cdot x 2$ & $-0,05 \pm 0,01$ & 0,00 & $0,00 \pm 0,01$ & 0,90 & $0,00 \pm 0,01$ & 0,63 & $0,01 \pm 0,01$ & 0,38 \\
\hline$x 1 \cdot x 3$ & $0,03 \pm 0,02$ & 0,12 & $0,02 \pm 0,02$ & 0,34 & $0,00 \pm 0,01$ & 0,88 & $0,01 \pm 0,01$ & 0,44 \\
\hline$x 3 \cdot x 4$ & $-0,01 \pm 0,02$ & 0,61 & $0,00 \pm 0,01$ & 0,89 & $0,02 \pm 0,01$ & 0,13 & $0,01 \pm 0,01$ & 0,36 \\
\hline$x 2 \cdot x 3$ & $-0,03 \pm 0,03$ & 0,24 & $-0,01 \pm 0,02$ & 0,60 & $0,03 \pm 0,02$ & 0,05 & $0,01 \pm 0,01$ & 0,62 \\
\hline$x 2 \cdot x 4$ & $0,00 \pm 0,02$ & 0,84 & $-0,01 \pm 0,01$ & 0,44 & $0,00 \pm 0,01$ & 0,70 & $-0,01 \pm 0,01$ & 0,38 \\
\hline$x 3 \cdot x 4$ & $-0,01 \pm 0,01$ & 0,41 & $-0,01 \pm 0,02$ & 0,35 & $-0,01 \pm 0,01$ & 0,25 & $0,00 \pm 0,01$ & 0,64 \\
\hline
\end{tabular}

Примітки: $r$ - константа; $x 1$ - чисельність $B$. bufo; $x 2$ - чисельність B. bombina; $x 3$ - чисельність $R$. arvalis; $x 4$ - чисельність P. fuscus.

Другий стаціонарний стан асимпотично стабільний, тому що найбільше власне число відповідної динамічної матриці є негативним $(-0,06+0,021 i)$. Слід відмітити, що число $є$ комплексним, це свідчить, що система повертається у стаціонарний стан за допомогою хвилеподібної динаміки. Динаміка повернення системи у стаціонарний стан не $\epsilon$ реактивною, оскільки всі власні числа матриці $\left(S+S^{T}\right) / 2$ негативні:

$$
\text { eigenvals }\left(\frac{\mathrm{S}+\mathrm{S}^{\mathrm{T}}}{2}\right)=\left(\begin{array}{c}
-0.008 \\
-0.078 \\
-0.155 \\
-0.291
\end{array}\right) \text {, }
$$

Слід зазначити, що найбільше власне число дуже наближене до нуля, тому, враховуючи стохастичну природу взаємодій між популяціями угруповання, можна припустити за певних умов реактивний характер динаміки угруповання. Це означас, що після пертурбації система перед тим, як повернутися до стаціонарного стану, може значно відхилятися у протилежному напрямку, що супроводжується варіабельністю показників чисельності. У реактивній системі варіабельність показників чисельності не $\epsilon$ показником стабільності або нестабільності. Збільшення варіабельності чисельності угруповання може бути необхідним етапом його стабілізації.

Наведений алгоритм було застосовано не тільки для даних щодо динаміки угруповання за весь період досліджень, а й для окремих його аспектів. Системи регресійних рівнянь і динамічні матриці у стаціонарних станах не наведено $з$ міркувань економії місця.
На тлі тотальної стійкості угруповання (для всього дослідженого часового та біогеоценотичного діапазонів) стійкість установлено тільки для одного стаціонарного стану у 2003 р. (табл. 4). Цей стійкий стан $є$ реактивним, а повернення до нього після виведення системи з рівноваги відбувається по коливальній траєкторії, про що свідчить наявність уявної компоненти у власному числі. За інші роки відповідні стаціонарні стани не є стійкими.

У сезонному аспекті всі стаціонарні стани не $\epsilon$ стійкими. Це свідчить, що закінчений річний цикл динаміки угруповання володіє властивостями стійкості, а сезонні етапи динаміки слугують тільки частинами траєкторії, у межах якої реалізується властивість стійкості.

У біогеоценотичному аспекті стійкістю характеризується один із стаціонарних станів угруповання в межах мертвопокривної та яглицевої парцел, тоді як у межах мокрицевої парцели угруповання не $є$ стійким. У мертвопокривній парцелі стійкий стан $є$ реактивним, а в яглицевій - не реактивним.

\section{Обговорення}

Установлено показники стійкості угруповання амфібій липово-ясеневої діброви у центральній заплаві р. Самара (ліва притока р. Дніпро, степова зона України) за Меєм та Ляпуновим. Обидва підходи базуються на припущенні про вплив кількості та інтенсивності зв'язків в угрупованні на його стійкість. Критерій Мея випливає 3 результатів числового моделювання гіпотетичних угру- 
повань (Мау, 1974). Його результативність підтверджена низкою польових досліджень (Mihaylovskiy, 1988), але ступінь відповідності експериментальних результатів теоретичним викладкам грунтується на експертних оцінках. Позитивна особливість критерію Мея - порівняна простота його обчислення, оскільки він є безпосередньою похідною кореляційної матриці угруповання. Саме кореляційні матриці є базисом для різного роду ординаційних технік в екології угруповань (факторний аналіз, аналіз відповідностей, кластерний аналіз, багатовимірне шкалювання та багато інших споріднених технік). Така методика дозволяе підійти до вирішення питання зв'язку стійкості та структури угруповання. Також критерій Мея дозволяє враховувати показник, який є функцією різноманіття угруповання, що пов'язує стійкість та різноманіття угруповання.

Показники стійкості угруповання амфібій по різних аспектах

Таблиия 4

\begin{tabular}{|c|c|c|c|c|c|c|c|}
\hline \multirow{3}{*}{$\begin{array}{c}\text { Аспект } \\
\text { угруповання }\end{array}$} & \multirow{2}{*}{\multicolumn{4}{|c|}{ Чисельності у стаціонарних станах }} & \multicolumn{3}{|c|}{ Показники стійкості за Ляпуновим } \\
\hline & & & & & \multirow{2}{*}{$\begin{array}{c}\text { найбільше власне } \\
\text { число динамічної } \\
\text { матриці }\end{array}$} & \multirow[b]{2}{*}{ еластичність } & \multirow[b]{2}{*}{ реактивність } \\
\hline & Bufo bufo & $\begin{array}{l}\text { Bombina } \\
\text { bombina }\end{array}$ & Rana arvalis & $\begin{array}{l}\text { Pelobates } \\
\text { fuscus }\end{array}$ & & & \\
\hline \multicolumn{8}{|c|}{ По роках } \\
\hline \multirow{2}{*}{2002} & 4,38 & 4,20 & 4,91 & 5,88 & 0,55 & $-1,82$ & 0,94 \\
\hline & 2,18 & 3,96 & 2,76 & 5,59 & $0,291+0,32 i$ & $-3,44$ & 0,34 \\
\hline \multirow{2}{*}{2003} & 4,30 & 6,36 & 9,07 & 8,52 & $-0,069+0,203 i$ & 14,49 & 0,15 \\
\hline & 4,70 & 5,25 & 3,73 & 6,26 & $0,193+0,1 i$ & $-5,18$ & 0,31 \\
\hline \multirow{2}{*}{2004} & 5,46 & 4,87 & 6,83 & 10,20 & $0,56+0,113 i$ & $-1,79$ & 0,61 \\
\hline & 4,57 & 3,85 & 4,80 & 4,45 & 0,36 & $-2,78$ & 0,38 \\
\hline \multicolumn{8}{|c|}{ По сезонах } \\
\hline \multirow{2}{*}{ Весна } & 0,30 & 3,15 & 7,97 & 14,53 & $0,04+1,118 i$ & $-25,00$ & 1,33 \\
\hline & 6,26 & 5,77 & 8,37 & 7,54 & 0,24 & $-4,17$ & 0,29 \\
\hline \multirow{2}{*}{ Літо } & 3,03 & 9,08 & 6,63 & 7,27 & $0,163+0,056 i$ & $-6,13$ & 0,22 \\
\hline & 10,81 & 5,05 & $-5,56$ & 11,83 & $0,582+0,235 i$ & $-1,72$ & 0,83 \\
\hline \multirow{2}{*}{ Осінь } & 5,94 & 4,94 & 4,68 & 7,65 & $0,379+0,133 i$ & $-2,64$ & 0,51 \\
\hline & 2,94 & 2,60 & 5,12 & 5,39 & $0,092+0,088 i$ & $-10,87$ & 0,15 \\
\hline \multicolumn{8}{|c|}{ По парцелах } \\
\hline \multirow{2}{*}{ Мокрицева } & 2,26 & 3,55 & 5,34 & 7,61 & $0,028+0,271 i$ & $-35,71$ & 1,13 \\
\hline & 5,26 & 9,12 & 13,70 & 14,41 & 0,18 & $-5,56$ & 0,33 \\
\hline \multirow{2}{*}{$\begin{array}{l}\text { Мертвопо- } \\
\text { кривна }\end{array}$} & 1,53 & 4,82 & 7,92 & 8,90 & $-0,086+0,099 i$ & 11,63 & $-0,03$ \\
\hline & 1,33 & 1,03 & 9,13 & 0,33 & $0,189+0,437 i$ & $-5,29$ & 0,35 \\
\hline \multirow{2}{*}{ Яглицева } & 2,84 & 4,57 & 5,26 & 5,93 & $-0,075+0,059 i$ & 13,33 & 0,01 \\
\hline & 6,65 & 4,41 & 6,47 & 9,53 & $0,371+0,116 i$ & $-2,70$ & 0,71 \\
\hline \multicolumn{8}{|c|}{ За весь період у всіх парцелах } \\
\hline \multirow{2}{*}{ Усього } & 4,66 & 2,74 & 4,03 & 4,16 & $0,221+0,03 i$ & $-4,52$ & 0,27 \\
\hline & 1,70 & 5,20 & 7,98 & 8,18 & $-0,06+0,021 \mathrm{i}$ & 16,67 & $-0,01$ \\
\hline
\end{tabular}

У свою чергу, складна динаміка компонентів угруповання, яка більшою мірою може бути описана нелінійними або навіть немонотонними нелінійними моделями, значно обмежує діапазон застосування процедури на основі індексів кореляції як Пірсона, так і Спірмена. Вірогідно як розширення критерію Мея може бути запропонована метрика, яка базується на інших, гнучкіших показниках зв'язку між видами в угрупованні, але розвиток підходів до оцінки різноманіття мав дещо інший напрям.

Альтернативним підходом до оцінювання стійкості угруповання є критерій Ляпунова, запозичений із теорії механічної стійкості. У ньому також стійкість виводиться через зв'язки між елементами системи, але ці зв'язки мають компоненту пам'яті взаємодії у часі: функцією, яка відображає зв'язок, є не чисельність виду, а швидкість зміни чисельності, тобто різниця між послідовною чисельністю у часі. Стійкість при такому підході формалізована як властивість повернення у стаціонарний стан системи після пертурбації, тобто відхилення системи від цього стану. У такому контексті мова йде не про стійкість системи як такої, а про стійкість стаціонарного стану. Складність поведінки системи може віддзеркалюватися наявністю не одного, а декількох стаціонарних станів. Система може вважатися стійкою, якщо існує стійкий хоча б один стаціонарний стан. Складна динаміка системи може бути описана системою нелінійних рівнянь. У стаціонарних станах проводиться лінеаризація, тобто спрощення до лінійної моделі системи диференціальних рівнянь в околиці стаціонарного стану. Найбільше за модулем власне число відповідної динамічної системи характеризує стійкість стаціонарного стану.

Як критерій Мея, так і критерій Ляпунова, дозволили встановити властивість стійкості угруповання амфібій у діапазоні часу дослідження та діапазоні досліджених парцел біогеоценозу. Окремі часові та біогеоценотичні аспекти угруповання не часто є стійкими. Це явище може бути пояснене за допомогою виявлення властивості реактивності, яке значно розширяє уявлення про стійкість угруповання. Реактивність виникає тоді, коли після пертурбації система ще більше відхиляється від рівноважного стану перед тим, як до нього повернутися. Локальні часові або біогеоценотичні зрізи віддзеркалюють саме ці періоди динаміки, коли система перебуває у значній віддаленості від стаціонарного стану та у цьому сенсі не $\epsilon$ стійкою. 
Установлені механізми стійкості угруповання амфібій мають значні природоохоронні висновки. Угруповання амфібій має біогеоценотичну та часову пам'ять. Екзогенні впливи навіть стійкої системи можуть у певному періоді часу посилюватися, оскільки угруповання $\epsilon$ реактивним. Тому варіабельність чисельності складових угруповання - не надійний маркер стійкості угруповання: стійке угруповання може складатися зі значно варіабельніших популяцій, а угруповання, яке втратило властивість стійкості, може тимчасово характеризуватися стабільною динамікою елементів.

Одержані результати підтверджують необхідність наявності довгострокових багаторічних моніторингових програм 3 оцінювання стану угруповань тварин, оскільки обмежені у часі зрізи стану не можуть мати вирішального значення у висвітленні їх стійкості.

Також одержані результати підтверджують роль біогеоценотичного (а у ширшому сенсі - ландшафтно-екологічного) різноманіття у формуванні властивості стійкості угруповань. Тому охорона біогеоценотичного різноманіття є основою підтримання стійкості угруповань амфібій.

\section{Висновки}

В межах липово-ясеневої діброви центральної заплави p. Самара угруповання амфібій характеризуються динамікою, яка може бути описана диференціально-різницевими рівняннями другого степеня. Така модель вказує на наявність двох стаціонарних станів надпопуляційної системи. Один із таких станів асимптотично стабільний, що вказує на стабільність усієї системи. Повернення системи у стабільний стаціонарний стан після пертурбації буде відбуватися за допомогою коливальної динаміки. Динамічна система не $\epsilon$ реактивною. Це свідчить, що після виведення з рівноважного стану система буде спрямована на безпосереднє повернення до нього.

\section{Бібліографічні посилання}

Armstrong, R.A., 1982. The effects of connectivity on community stability. Am. Nat. 120, 391-402.

Asara, Ö., Ilkb, O., Dagc, O., 2015. Estimating Box-Cox power transformation parameter via goodness of fit tests. Communications in Statistics - Simulation and Computation 12.

Beddington, J., Free, C., Lawton, J., 1976. Concepts of stability and resilience in predator - prey models. J. Anim. Ecol. 45, 791-816.

Bikov, B.A., 1983. Jekologicheskij slovar' [Ecological dictionary]. Nauka, Alma-Ata (in Russian).

Bulakhov, V.L., Gasso, V.Y., Pakhomov, O.Y., 2007. Biologichne riznomanittja. Dnipropetrovs'ka oblast'. Amfibii ta reptilii [Biological Diversity of Ukraine. The Dnipropetrovsk region. Amphibians and Reptiles (Amphibia et Reptilia)]. Dnipropetrovsk Univ. Press, Dnipropetrovsk (in Ukrainian).

Carik, L., 2010. Samovidnovlennja populjacij za riznih umov jikh rostu [Independent restore populations in various conditions of their growth]. Vìsn. Lviv. Unìv. Ser. Bìol. 53, 94-99 (in Ukrainian).

Carpenter, S.R., Kraft, C.E., Wright, R., 1992. Resilience and resistance of alake phosphorus cycle before and after a food web manipulation. Am. Nat. 140, 781-798.
Chase, J.M., 1996. Differential competitive interactions and the included niche: An experimental analysis with grasshoppers. Oikos 76, 103-112.

Chen, X., Cohen, J., 2001 Transient dynamic and food-web complexity in the Lotka-Volterra cascade model. Proc. Roy. Soc. London 268, 869-877.

Cottingham, K.L., Carpenter, S.R., 1994. Predictive indices of ecosystem resilience in models of north temperate lakes. Ecology 75, 2127-2138.

DeAngelis, D.L., 1980. Energy flow, nutrient cycling, and ecosystem resilience. Ecology 61, 764-771.

DeAngelis, D.L., Bartell, S.M., Brenkert, A.L., 1989. Effects of nutrient recycling and food chain length on resilience. Am. Nat. 134, 778-805.

DeAngelis, D.L., Mulholland, P.J., Palumbo, A.V., 1989. Nutrient dynamics and food-web stability. Annu. Rev. Ecol. Syst. 20,71-95.

Elzanowski, A., Cieslewicz, J., Kaczor, M., 2009. Amphibian road mortality in Europe: A meta-analysis with new data from Poland. Eur. J. Wildlife Res. 55, 33-43.

Hallett, J.G., Pimm, S.L., 1979. Direct estimation of competition. Am. Nat. 113, 593-599.

Harrison, G., 1979. Stability under environmental stress: Resistance, resilience, persistence, and variability. Am. Nat. 113, 659-669.

Harwell, M.A., Cropper, W.P., Ragsdale, H.L., 1977. Nutrient recycling and stability: A reevaluation. Ecology 58, 660-666.

Harwell, M.A., Cropper, W.P., Ragsdale, H.L., 1981. Analysis of transient characteristics of a nutrient cycling model. Ecol. Model. 12, 105-131.

Harwell, M.A., Ragsdale, H.L., 1979. Eigengroup analyses of linear ecosystem models. Ecol. Model. 7, 239-255.

Holling, C., 1973. Resilience and stability of ecological systems. Annu. Rev. Ecol. Syst. 4, 1-23.

Ishhenko, V.G., 2007. Zhiznennyj reproduktivnyj uspeh i struktura populjacii ostromordoj ljagushki (Rana arvalis Nilss., 1842) [Vital reproductive success and population structure of Rana arvalis]. Sovremennaja Gerpetologija 1, 76-87 (in Russian).

Jordan, C.F., Kline, J.R., Sasscer, D.S., 1972. Relative stability of mineral cycles in forest ecosystems. Am. Nat. 106, 237-253.

Kusak, J., Huber, D.R., Gomerčić, T., Schwaderer, G., Gužvica, G., 2009. The permeability of highway in Gorski kotar (Croatia) for large mammals. Eur. J. Wildlife Res. 55, 7-21.

Laska, M.S., Wootton, J.T., 1998. Theoretical concepts and empirical approaches to measuring interaction strength. Ecology 79(2), 461-476.

Lee, J.J., Inman, D.L., 1975. The ecological role of consumers an aggregated systems view. Ecology 56, 1455-1458.

Loreau, M., 1994. Material cycling and the stability of ecosystems. Am. Nat. 143, 508-513.

MacArthur, R.H., Levins, R., 1967. The limiting similarity, convergence, and divergence of coexisting species. Am. Nat. 101, 377-385.

May, R.M., 1974. Stability and complexity in model ecosystems. Princeton University Press, Princeton, USA.

Mihaylovskiy, G.E., 1988. Opisanie i otsenka sostoyaniya planktonnyih soobschestv [Description ane assessment of the plankton community state]. Nauka, Moscow (in Russian).

Nakajima, H., 1992. Sensitivity and stability of flow networks. Ecol. Model. 62, 123-133.

Navarro, D.J., 2015. Learning statistics with R: A tutorial for psychology students and other beginners. (Version 0.5) University of Adelaide, Adelaide, Australia.

Neubert, M.G., Caswell, H., 1997. Alternatives to resilience for measuring the responses of ecological systems to perturbation. Ecology 78(3), 653-665.

O'Neill, R.V., 1976. Ecosystem persistence and heterotrophic regulation. Ecology 57, 1244-1253. 
Orlowski, G., Nowak, L., 2004. Road mortality of hedgehogs Erinaceus spp. in farmland in Lower Silesia (South-Western Poland). Pol. J. Ecol. 52(3), 377-382.

Pakhomov, O.Y., Gasso, V.Y., Goloborodko, K.K., Poljakov, M.V., Grycan, Y.I., Bulakhov, V.L., Brygadyrenko, V.V., Kljuchko, Z.F., Mezhzherin, S.V., Novicky, R.O., Pysanec, Y.M., Pljushh, I.G., Ponomarenko, O.L., Puchkov, O.V., Radchenko, V.G., 2011. Chervona knyga Dnipropetrovskoi oblasti. Tvarynnyj svit [The red book of Dnipropetrovsk region. Animals]. New Print, Dnipropetrovsk (in Ukrainian).

Pfister, C.A. 1995. Estimating competition coefficients from census data: A test with field manipulations of tide pool fishes. Am. Nat. 146, 271-291.

Pianka, E.R., 1973. The structure of lizard communities. Annu. Rev. Ecol. Syst. 4, 53-74.

Pimm, S.L., 1979. The structure of food webs. Theor. Popul. Biol. 16, 144-158

Pimm, S.L., 1984. The complexity and stability of ecosystems. Nature 307, 321-326.

Pimm, S.L., Lawton, J.H., 1977. Number of trophic levels in ecological communities. Nature 268, 329-331.

Pimm, S.L., Lawton, J.H., 1978. On feeding on more than one trophic level. Nature 275, 542-544.

Reshetilo, O., 2013. Mehanizmi samovidnovlennya populyaciy zemnovodnih u visokogiryi Ukrainskih Karpat [The mechanisms of amphibian populations' self-Renewalin the highmountains of Ukrainian Carpathians]. Vìsn. Lviv. Unìv. Ser. Bìol. 62, 152-159 (in Ukrainian).
Ricklefs, R.E., Travis, J., 1980. A morphological approach to the study of avian community organization. Auk 97, 321-338.

Schoener, T.W. 1974. Competition and the form of habitat shift. Theor. Popul. Biol. 6, 265-307.

Shadrin, N.V., 2012. Dinamika jekosistem i jevoljucija: Mnozhestvennost' ustojchivyh sostojanij i tochki oprokidyvanija / nevozvrata. Neobhodimost' novogo ponimanija [Ecosystem dynamics and evolution: Multiplicity of steady states and tipping points. Necessity of new understanding]. Marine Ecological Journal 11(2), 85-95 (in Russian).

Sumarokov, O., Zhukov, O., 2007. Obosnovanie vosstanovlenija jekologicheskogo potenciala agrobiogeocenozov pri umen'shenii pesticidnyh nagruzok $\mathrm{v}$ Ukraine [The rationale is to restore the ecological potential agrobiocenoses while reducing pesticide loads in Ukraine]. Izv. Hark. Jentomol. O-va. 14(12), $145-154$

Vincent, T.L., Anderson, L.R., 1979. Return time and vulnerability for a food chain model. Theor. Popul. Biol. 15, 217-231.

Wootton, J.T., 1994. Putting the pieces together: Testing the independence of interactions among organisms. Ecology 75, 1544-1551.

Zhukov, O.V., Gubanova, N.L., 2015. Riznomanittya ta dynamika uhrupovan' zemnovodnykh zaplavnykh ekosystem r. Samara-Dniprovs'ka [Diversity and dynamic of flooded ecosystems anura community]. Vìsn. Dnìpropetr. Unìv. Ser. Bìol. Ekol. 23(1), 66-73.

Надійшла до редколегії 12.09.2015 